\title{
Mutual Funds-A Pragmatic Research on Investors Perception Towards Risk-Return Pattern with Special Reference to Coimbatore City
}

\author{
K.P. Sowmya, Sandiya.C, Shanthini.C
}

\begin{abstract}
Mutual funds act as a medium for retail investors to invest their savings in the professional fund's management system, irrespective of the sum invested. The industry of mutual fund has come a long way in predicting the investor's sufficient growth of their thoughts of investing in such fund houses in large numbers. The basic drive of an investment to get a maximum return with a minimum risk where the mutual fund provides the opportunity for it. The research provides the statistical data analysis through the investor's perception of mutual funds, understanding about the growth and the riskreturn of the investors. The data has been analysed from mutual fund investors. It mainly focuses on the investor's point of view towards the mutual fund schemes which is predictable in the future rate of investment and the growth and risk factors involved. It was found that low risk funds and liquidity of funds scheme are having influence on the investor's perception for investing in the mutual fund.
\end{abstract}

Keywords: Perception, risk-return, investors, precarious

\section{INTRODUCTION}

"Risk comes from not knowing what you are doing"

An investment that pools money from investors is what makes mutual funds. A mutual fund can seem to be more or less complicated or intimidating. Mutual fund investment has become popular as one of the safest, easiest, convenient and successful investment. A mutual fund portfolio is designed and maintained to match its objectives stated in the investment process. Mutual fund investment offers various benefits that make them the most lucrative investment options. People investing in mutual funds have thought of risk and return involved where they are investing in mutual fund schemes. By understanding their perception towards mutual funds investors may find it quite difficult to analyze funds by considering the factors mentioned related to the schemes. As an investor, we can either manage our finance by investing in funds by hiring a thought of returns for future benefits.

A mutual fund investor invests his money on the basis of the risk involved, the main issues found while investing in mutual funds are losing money. Mutual funds are subject to market risk. It includes various risk such as credit risk, interest rate risk, price risk, economic risk. Depending upon these risk factors people pretend to invest in mutual schemes. From an investors point of view, they have to think twice before investing and has to analyze the risk involved and then proceed for the investment process. Thus, investing in mutual funds impacts on investors preferential needs and predictable to the future rate of investment and the growth and risk factors involved.

\section{OBJECTIVE OF THE STUDY}

1. To know about the investors preference towards the mutual fund schemes.

2. To understand about the growth and risk - return of the investors.

3. To know about the problems faced by the investors.

\section{STATEMENT OF PROBLEM}

In today's upcoming world people have a higher thought of investing their salaries in various schemes of investment depending upon its future benefits. Mutual funds seems to be the most advanced upcoming investment needs has it depends upon the market value, which may furnish a higher as well as lower value of risk and return. At investors point of view, the complete detail analyzed was their perception towards it and how they face the growth and the risk-return involved in it. A mutual fund investors may invest his funds on the advice of the broker, agents or other banking or online fund institutions. People have to cogitate before funding their money in different schemes of mutual funds and should have a comparative analysis of which plan has a higher profit of risk and return in both past and future aspects.

\section{SCOPE OF THE STUDY}

The exploration of this paper basically focuses on investors point of view towards the mutual fund schemes and it's growth in the future, it also focuses on the risk factor involved which restricts investors in investing in mutual funds. Thus, the study provides a complete picture of investors intention on the mutual fund which includes it's risk analyses, various schemes they have invested, profit earned or any losses incurred.

Revised Manuscript Received on September 14, 2019.

K.P. Sowmya, Assistant Professor, Sri Krishna Arts and Science College/ Bharathiar University, Coimbatore, Tamilnadu, India.(E-mail: sowmyakp@skasc.ac.in)

Sandiya.C, II B.COM AF, Sri Krishna Arts and Science College/ Bharathiar University, Coimbatore, Tamilnadu, India.(E-mail: sandiyac18bcf045@skasc.ac.in)

Shanthini.C, II B.com AF, Sri Krishna Arts and Science College/ Bharathiar University, Coimbatore, Tamilnadu, India.(E-mail: shanthinic18bcf048@skasc.ac.in) 


\section{RESEARCH METHODOLOGY}

Research methodology is a precise way to solve the research problem. It is how research is done scientifically. It consists of different steps that are generally adopted by a researcher to study the research problem along with the

\section{A) SOURCES OF DATA \\ 1. PRIMARY DATA \\ 2. SECONDARY DATA \\ B) COLLECTION OF DATA \\ i) Primary data}

Structured questionnaires were prepared for the purpose of collection of primary data from the respondents. The questionnaire was prepared in a simple and understandable way so as to express their views freely and frankly.

\section{ii) Secondary data}

Secondary data were collected from magazines, newspaper, journals, and websites

\section{C) AREA OF THE STUDY}

Area of the study refers to Coimbatore city which is known for a textile mill, hospitals, and educational institutions. Coimbatore is known as the Manchester of South India. Coimbatore is now becoming a city of the tidal park. In view of the larger establishment of business houses and institutions, people in Coimbatore have an opportunity to have their own lifestyle and affordability.

\section{D) SAMPLING SIZE AND POPULATION}

The sample size is 508 questionnaire collected from the different respondents. Convenient sampling method is used for the study. The result of the study will help the customer to know about the postal schemes in depth. This study covers only the Customers who are residing in the geographical location of Coimbatore town.

\section{E) PERIOD OF STUDY}

Period of study is from April 2019 to September 2019.

\section{F) STATISTICAL TOOLS FOR THE STUDY}

* Simple percentage analysis
* Chi-square analysis
Weighted average scores analysis

\section{LIMITATION OF THE STUDY:}

The following are the limitations only:

* The study was limited to Coimbatore city only.

* The sample size was limited to 508 respondents.

* The data was obtained through questionnaire and it may not be accurate.

\section{REVIEW OF LITERATURE}

De Bondat and Thaler (1985) has invested through the psychological behaviour of an investor that they depend upon the mean reversion of the stock price in the market which is the evidence of investors thought regarding the present firm's performance reacting towards the future expectation. logic behind them.

John MCDonald (1974) has examined the relationship between the intent fund and their risk and return attributes. The study has proved that the minimum of fund managers has appeared to keep their portfolios up to the stated risk. He also analysed that some of the low-risk fund's group possessed higher risk funds in the risk groups..

\section{ANALYSIS AND INTERPRETATION}

Table no. 1

Demographic Profileof The Respondents

\begin{tabular}{|l|l|l|l|}
\hline S.NO & PARTICULARS & NUMBER & PERCENTAGE \\
\hline GENDER & \multicolumn{2}{|l|}{} \\
\hline 1 & Male & 262 & 50 \\
\hline 2 & Female & 246 & 47 \\
\hline AGE GROUP & \multicolumn{2}{|l|}{} \\
\hline 1 & below 30 & 422 & 81 \\
\hline 2 & $31-40$ & 25 & 5 \\
\hline 3 & $41-50$ & 11 & 3 \\
\hline 4 & Above 50 & 50 & 10 \\
\hline OCCUPATION STATUS & \multicolumn{2}{|l|}{} \\
\hline $\mathbf{1}$ & Employed & 114 & 22 \\
\hline $\mathbf{2}$ & Business & 205 & 39 \\
\hline $\mathbf{3}$ & Professional & 142 & 27 \\
\hline $\mathbf{4}$ & Retired persons & 47 & 12 \\
\hline
\end{tabular}

From the above analytical data out of 508 respondents , $50 \%$ of the respondents are male and $47 \%$ of the respondents are female whereas $81 \%$ of the respondents are below the age group of $30,5 \%$ of the respondents are between $31-40,3 \%$ of the respondents are below 41-50, $10 \%$ of the respondents are above the age group of 50 and $22 \%$ of the respondents are employed, $39 \%$ of the respondents are business, $27 \%$ of the respondents are professionals and $12 \%$ of the respondents are retired persons.

\section{Chi-square analysis:}

Relationship between the monthly income earned and percent of income they set aside for investment.

\section{Hypothesis:}

The educational qualification of the respondents is significant to the the schemes the investor has invested in mutual fund.

Table No :2

Chi-square value - monthly income and the per cent set aside for investment

\begin{tabular}{|l|r|r|r|}
\hline & \multicolumn{1}{c|}{ Value } & \multicolumn{1}{|c|}{ Df } & \multicolumn{1}{c|}{$\begin{array}{c}\text { Asymp. Sig. } \\
\text { (2-sided) }\end{array}$} \\
\hline Pearson Chi-Square & $1214.361^{\mathrm{a}}$ & 28 & .000 \\
Likelihood Ratio & 985.935 & 28 & .000 \\
Linear-by-Linear & .198 & 1 & .656 \\
Association & 508 & & \\
N of Valid Cases & & & \\
\hline
\end{tabular}

Note: S-Significant ( $\mathrm{p}$ value $\leq 0.05$ ): Ns-No significant $(\mathrm{p}$ value $\geq 0.0$ 
It is an proof from the above table that the hypothesis is

IX. AVERAGE RANK ANALYSIS

accepted, it is significant were it is less than 0.005 .

Table No: 3

Factors influencing the consumer

\begin{tabular}{|c|c|c|c|c|c|c|c|c|c|c|c|c|c|c|}
\hline \multirow{2}{*}{ S.No } & \multirow{2}{*}{ Factors } & Rank & 1 & 2 & 3 & 4 & 5 & 6 & 7 & 8 & 9 & 10 & \multirow{2}{*}{ Mean } & \multirow{2}{*}{ Rank } \\
\hline & & Value & 10 & 9 & 8 & 7 & 6 & 5 & 4 & 3 & 2 & 1 & & \\
\hline $\mathrm{a}$ & $\begin{array}{l}\text { Lack of } \\
\text { information }\end{array}$ & No & 0 & 150 & 0 & 0 & 0 & 250 & 0 & 108 & 0 & 0 & 5.756 & VII \\
\hline $\mathrm{b}$ & $\begin{array}{l}\text { Lack of } \\
\text { initiatives }\end{array}$ & No & 0 & 0 & 254 & 0 & 196 & 0 & 0 & 0 & 58 & 0 & 6.315 & IV \\
\hline $\mathrm{c}$ & $\begin{array}{l}\text { Insufficient } \\
\text { agent and } \\
\text { brokers }\end{array}$ & No & 63 & 0 & 208 & 0 & 177 & 0 & 0 & 60 & 0 & 0 & 6.961 & II \\
\hline d & low return & No & 0 & 0 & 0 & 0 & 0 & 0 & 65 & 86 & 0 & 357 & 1.722 & $\mathbf{X}$ \\
\hline $\mathrm{e}$ & high risk & No & 156 & 0 & 0 & 38 & 123 & 67 & 30 & 40 & 0 & 54 & 6.285 & $\mathbf{V}$ \\
\hline $\mathrm{f}$ & $\begin{array}{l}\text { No } \\
\text { knowlege } \\
\text { about where } \\
\text { to invest }\end{array}$ & No & 0 & 34 & 0 & 85 & 0 & 0 & 237 & 0 & 152 & 0 & 4.238 & IX \\
\hline g & $\begin{array}{l}\text { Lack of } \\
\text { market } \\
\text { information }\end{array}$ & No & 54 & 102 & 254 & 0 & 0 & 98 & 0 & 0 & 0 & 0 & 6.827 & III \\
\hline $\mathrm{h}$ & $\begin{array}{l}\text { Satisfactory } \\
\text { return on } \\
\text { investment }\end{array}$ & No & 0 & 203 & 0 & 12 & 0 & 0 & 207 & 19 & 0 & 67 & 5.504 & VIII \\
\hline $\mathrm{i}$ & $\begin{array}{l}\text { Satisfied } \\
\text { with agent } \\
\text { and broker }\end{array}$ & No & 0 & 85 & 95 & 0 & 144 & 0 & 104 & 80 & 0 & 0 & 5.994 & VI \\
\hline $\mathrm{j}$ & $\begin{array}{l}\text { Knowledge } \\
\text { about how } \\
\text { to invest }\end{array}$ & No & 422 & 0 & 86 & 0 & 0 & 0 & 0 & 0 & 0 & 0 & 9.661 & I \\
\hline
\end{tabular}

Among the various problems faced by investors during their investment decision, most of the respondents have given that they lack the Knowledge about how to investment followed by Insufficient agent and brokers information.

\section{CONCLUSION}

Many people have a high thought of investing their annual income in one or the other. Mutual fund differs from other investment options as they provide a higher rate of return where it totally depends on its market value. The study here has taken analyses from mutual fund investors who have invested their income in MF schemes and the risk or problems faced by them after or before investing in mutual fund schemes. Investment is one of the most preferable for the future benefits of a person saving. According to the fact, people intend to invest in MF schemes as they pretend to face the risk factor involved in it. This paper basically focuses on the which point they lack their thought on investing in mutual funds.

\section{REFERENCES}

1 Investment performance on international mutual fund William G. Droms, DavidA. Walker.
2 www. Academic.edu

3 performance evaluation of mutual fund schemes : a study selected selected topper schemes. - geeta rani, vijay Singh Hooda 